\title{
Mesoscale modeling of combined aerosol and photo-oxidant processes in the Eastern Mediterranean
}

\author{
M. Lazaridis ${ }^{1}$, A. Spyridaki ${ }^{1}$, S. Solberg ${ }^{2}$, J. Smolík ${ }^{3}$, V. Ždímal ${ }^{3}$, K. Eleftheriadis ${ }^{4}$, V. Aleksanropoulou ${ }^{1}$, O. Hov ${ }^{5}$, \\ and P. G. Georgopoulos ${ }^{6}$ \\ ${ }^{1}$ Technical University of Crete, Department of Environmental Engineering, 73100 Chania, Greece \\ ${ }^{2}$ Norwegian Institute for Air Research (NILU), P.O. Box 100, NO-2007 Kjeller, Norway \\ ${ }^{3}$ Institute of Chemical Process Fundamentals, ASCR, Prague, Czech Republic \\ ${ }^{4}$ N.C.S.R. "Demokritos", 15310 Agia Paraskevi, Athens, Greece \\ ${ }^{5}$ Norwegian Meteorological Institute, P.O. Box 43, Blindern NO-0313 Oslo, Norway \\ ${ }^{6}$ EOHSI, University of Medicine and Dentistry and Rutgers University, New Jersey, NJ, USA
}

Received: 11 June 2004 - Published in Atmos. Chem. Phys. Discuss.: 21 September 2004

Revised: 29 December 2004 - Accepted: 4 March 2005 - Published: 21 March 2005

\begin{abstract}
Particulate matter and photo-oxidant processes in the Eastern Mediterranean have been studied using the UAM-AERO mesoscale air quality model in conjunction with the NILU-CTM regional model. Meteorological data were obtained from the RAMS prognostic meteorological model. The modeling domain includes the eastern Mediterranean area between the Greek mainland and the island of Crete. The modeling system is applied to study the atmospheric processes in three periods, i.e. 13-16 July 2000, 2630 July 2000 and 7-14 January 2001. The spatial and temporal distributions of both gaseous and particulate matter pollutants have been extensively studied together with the identification of major emission sources in the area. The modeling results were compared with field data obtained in the same period. The objective of the current modeling work was mainly to apply the UAM-AERO mesoscale model in the eastern Mediterranean in order to assess the performed field campaigns and determine that the applied mesoscale model is fit for this purpose. Comparison of the modeling results with measured data was performed for a number of gaseous and aerosol species. The UAM-AERO model underestimates the $\mathrm{PM}_{10}$ measured concentrations during summer and winter campaigns. Discrepancies between modeled and measured data are attributed to unresolved particulate matter emissions. Particulate matter in the area is mainly composed by sulphate, sea salt and crustal materials, and with significant amounts of nitrate, ammonium and organics. During winter the particulate matter and oxidant concentrations were lower than the summer values.
\end{abstract}

Correspondence to: $\mathrm{M}$. Lazaridis

(lazaridi@mred.tuc.gr)

\section{Introduction}

Airborne particulate matter and photo-oxidants are important aspects of air pollution with very diverse effects ranging from human health to climate forcing. A major part of the aerosol mass is secondary particulate matter in the form of sulphate, nitrate, ammonium and organic aerosol particles formed by the oxidation of sulphur dioxide, nitrogen oxides and organic gaseous species. It is apparent that particulate matter is not a single pollutant and its mass includes a size dependent mixture of many pollutants.

In Southern Europe large changes have occurred over the past few decades linked to the increase in population, and land-use alterations, impacting on atmospheric composition, water availability and consequently on quality of life, including human health. For instance, most chemistry-transport models predict that the high ozone concentrations observed in summer over Europe have a maximum around the Mediterranean sea, and in particular in its Eastern part, very often exceeding the air quality standards. Often high concentrations of fine particles are observed together with high ozone concentrations (Lelieveld et al., 2002; Smolík et al., 2003). Here natural emissions of highly reactive unsaturated hydrocarbons (including isoprene) and continuing high emissions of anthropogenic gaseous and aerosol pollutants in Southern Europe contribute (Hoffman et al., 1997; Pandis et al., 1992; Kavouras et al., 1998; Sotiropoulou et al., 2004). Experimental measurements and estimates (Pandis et al., 1992) also indicate that there are highly nonlinear aspects involved in the production of organic aerosols, e.g. in the aerosol yields from monoterpenes. In addition, pressures from anthropogenic activity on the Mediterranean area have complex consequences for the quality of life and the regional radiative forcing of climate.

(C) 2005 Author(s). This work is licensed under a Creative Commons License. 

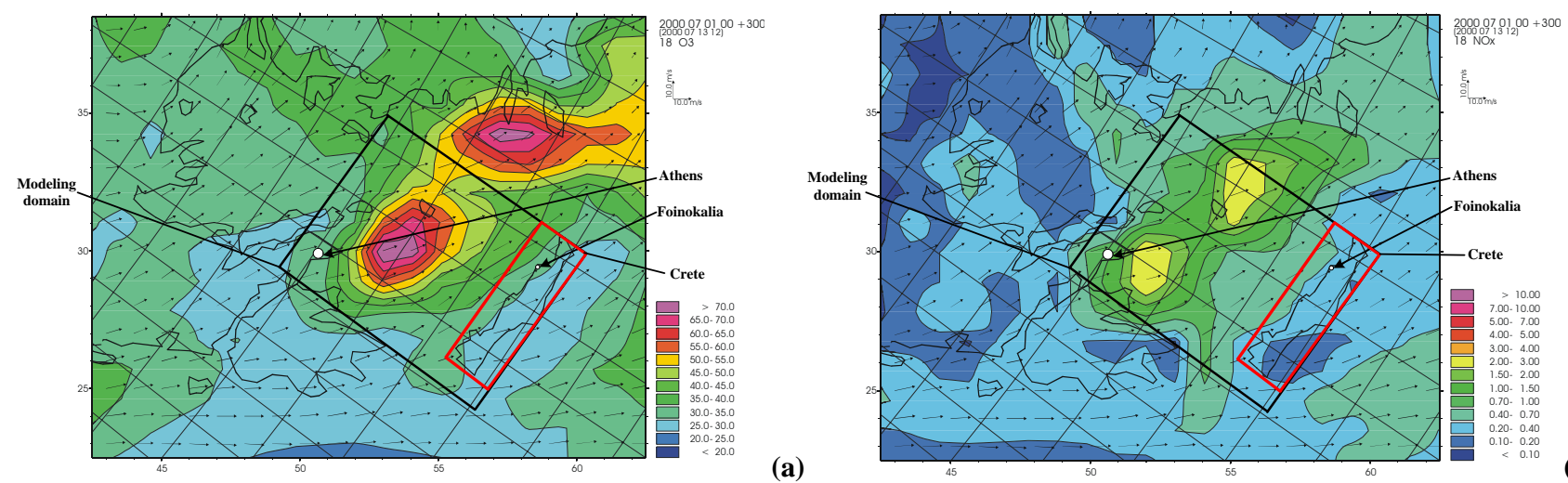

(b)

Fig. 1. Simulation results of the (a) ozone and (b) nitrogen oxides surface mixing ratio for an extended grid using the CTM-NILU regional model (unit in ppb) on 13 July 2000 (12:00 h, level 18, surface layer). Compare Fig. 4a.

From this follows that there is a need to study the physicochemical processes which control the dynamics of aerosols and photo-oxidants in the Mediterranean area combining modeling and field studies. Information is still scarce to support measurement and modelling studies in a consistent way across the regional, mesoscale and local spatial scales to reveal the atmospheric composition and variability of particulate matter (PM) (Ackermann et al., 1998; Lurmann et al., 1997; Seigneur, 2001; Russell and Dennis, 2000; Pilinis and Seinfeld, 1987).

Two extensive measurement campaigns were performed to examine the characteristics and dynamics of photochemical pollutants and fine particles in the Eastern Mediterranean area between the Greek mainland and the island of Crete (Smolík et al., 2003). Sampling took place during 4 weeks in July 2000 and 1 week in January 2001 at the Finokalia station and onboard the research vessel "Aigeaion". The Finokalia station $\left(35^{\circ} 19^{\prime} \mathrm{N}, 25^{\circ} 40^{\prime} \mathrm{E}\right)$ is a remote coastal site eastward of Herakleion (the largest city of the island) atop a hill (elevation $130 \mathrm{~m}$ ) facing the sea within the sector from $270^{\circ}$ to $90^{\circ}$ (Mihalopoulos et al., 1997).

Mihalopoulos et al. (1997) describe the Finokalia site in detail and report concentrations of the major soluble ions collected over a one-year period. Ozone concentrations at Finokalia exhibit a well-defined seasonal cycle with a maximum during the summer months and elevated levels (up to $80 \mathrm{ppbv}$ ) during daytime (summer) and over time periods of several days (summer) (Kouvarakis et al., 2000). Furthermore, ozone levels in the Eastern Mediterranean seem to be dominated by long range transport (Kouvarakis et al., 2000). In addition, non sea salt sulphate (Nss-SO $\mathrm{SO}_{4}$ ) and the $\mathrm{SO}_{2} \mathrm{lev}$ els in Eastern Mediterranean were strongly influenced by regional transport (Sciare et al., 2003).

During the measurement campaigns an extensive set of instrumentation was employed to determine the physicochemical characteristics of aerosol and gaseous pollutants. In particular, measurements focused on size-resolved sam- pling for the aerosol mass on a daily basis with subsequent analysis for ionic species, crustal and trace elements. In addition, total aerosol mass, equilibrium trace gases, as well as detailed size-distribution measurements in terms of aerosol number by optical and differential mobility methods for the fine aerosol fraction were undertaken. Other complementary measurements included black carbon concentration by optical transmission methods, aerosol optical properties, and thermal analysis of selected samples. Relevant photooxidants and inorganic trace gases were monitored by prototype and conventional instruments.

Photochemical modeling is a necessary component in the study of the dynamics of gaseous pollutants and particulate matter, providing a platform for the understanding of the variability and spatial-temporal patterns of these pollutants (Pilinis and Seinfeld, 1987; Binkowski and Shankar, 1995; Lurmann et al., 1997; Ackermann et al., 1998; Pai et al., 2000; Jacobson, 1997). A combined intensive modelling study and comparison with available experimental data for ozone/fine particles in the Mediterranean area should offer valuable information for characterizing their dynamics and association. The current modelling work covers short periods in summer and winter and the findings of this work have to be seen in perspective and in relation with previous works in the region (Zerefos et al., 2002; Bardouki et al., 2003; Sciare et al., 2003; Kouvarakis et al., 2000).

The objective of the current modeling work is mainly to apply the UAM-AERO mesoscale model in the eastern Mediterranean in order to assess the performed field campaigns and determine that the applied mesoscale model is fit for this purpose.

A detailed modeling study has been performed using the UAM-AERO mesoscale air quality model (Lurmann et al., 1997). Meteorological input data were provided by the RAMS (Pielke et al., 1992) prognostic meteorological model whereas gaseous regional data on background concentration were obtained from the NILU-CTM model (Flatøy et al., 
2000) and on particulate matter from the EMEP model (ApSimon et al., 2001). The present study represents one of the first applications of a modified UAM-AERO model combined with the prognostic meteorological model (RAMS) for the southern Mediterranean and comparison between modeled and measured data for particulate matter. In addition, the current modeling application is one of the first ones to study combined aerosol and photo-oxidant processes together with extensive comparisons with field data.

Predicted concentrations patterns of aerosols and gaseous species in the eastern Mediterranean area show that long range transport and natural emission sources are important. The term "long range transport" in the discussion of the modelling results refers to transport from outside the modelling UAM-AERO domain. As in previous studies (Lurmann et al., 1997), the model results depend mainly on the characteristics of the particulate matter emissions. Determination of the wind driven resuspension of aerosols is required to evaluate the crustal material contribution to the aerosol mass size distribution. Poor agreement mainly during the summer period for specific particulate matter chemical components reflects the uncertainty in the emission inventory data.

\section{Material and methods}

\subsection{Description of the domain}

The model domain $(58 \times 74$ grid points), covers SE Greece (the inner black rectangular included in Fig. 1). Five vertical layers were used: two below and three above the diffusion break. The grid was defined in the UTM coordinate system. The UTM zone 34 was used for the definition of the grid above Greece, which means a central meridian of $21^{\circ} \mathrm{E}$. The SW corner coordinates of the grid are the following (according to the WGS84 system) Easting: 692089 and Northing: 3868229 . This corresponds to the geographical coordinates: $34^{\circ} 56^{\prime} 08^{\prime \prime}$ latitude and $23^{\circ} 06^{\prime} 02^{\prime \prime}$ longitude.

The region of interest includes marine (the Aegean and Cretan Seas), island (Cyclades, Crete) and continental (Attica and Peloponnesus) parts of southern Greece. A complicated topography (high mountains, deep sea and scattered small islands), combined with the long sunny and humid periods, strong winds and one of the most polluted European cities (Athens) to the NW, inhabited by almost half of the country's population, characterize the region.

In the southern part of the modeling domain is the island of Crete, mid-distance between Athens and the northern African coast. It is mainly mountainous, with all major cities located at the north coast. The total population rises up to 600000 , while at summer periods this number can increase significantly, due to high load of tourism, part of which is scattered all over the island, but the majority is mainly concentrated along the northern coast.
The modelling results are compared with extensive measurements performed at Finokalia which is a remote coastal site, situated on the top of a hill (elevation $130 \mathrm{~m}$ ), on the NE part of the island (Smolík et al., 2003). In addition, the modelling results were compared with measurements performed on board a research vessel during July 2000 and with some data from the city of Herakleion on Crete, $70 \mathrm{~km}$ to the west of Finokalia.

The emissions inputs, except for $\mathrm{PM}_{10}$ obtained from TNO (Berdowski et al., 1998), are from the EMEP database, from the CTM-NILU regional model (initial and background concentrations) and from detailed emission inventories for biogenic species (isoprene and terpenes), resuspended dust and sea salt (Aleksandropoulou and Lazaridis, 2004; Lazaridis et al., 2003). The concentrations for the 24 gaseous species considered in the NILU-CTM regional model were used for the simulations performed with the UAM-AERO model as the background and initial concentrations (Flatøy et al., 2000). However, the NILU-CTM model does not implement particulate matter emissions.

The spatial distribution of the emissions of $\mathrm{CO}, \mathrm{SO}_{\mathrm{x}}$, $\mathrm{NO}_{\mathrm{x}}, \mathrm{NMVOC}, \mathrm{NH}_{3}$ and $\mathrm{PM}$ was improved on the basis of the allocation of emissions as given by EMEP/CORINAIR, 2002, landuse and population density data. Particular focus was on the estimation of natural emissions and especially NMVOC (isoprene, terpene) emitted by vegetation, sea salt particles and resuspended soil dust (Andreae, 1995; Aleksandropoulou and Lazaridis, 2004).

Emission estimates were compiled using the methodology given in "Atmospheric Emissions Inventory Guidebook", CORINAIR (EMEP/CORINAIR, 2002). A bottom-up approach based on land use and meteorology data is followed in the evaluation of biogenic and natural emissions (Simpson et al., 1995, 1999). Natural emissions were calculated with hourly temporal resolution, anthropogenic data as annual averages. The emissions were allocated on a $5 \times 5 \mathrm{~km}^{2}$ grid.

An example of the surface background concentrations of ozone and nitrogen dioxide calculated with the CTM-NILU model is presented in Fig. 1. High ozone and $\mathrm{NO}_{\mathrm{x}}$ concentrations are calculated downwind of the Athens metropolitan area. The above initial concentrations, representing 3-D hourly values (in ppb) were used as background concentrations of the domain which is modeled with the UAM-AERO model.

2.2 The three-dimensional photochemical modeling and prognostic meteorological tools

The UAM-AERO mesoscale model is a gas/aerosol air quality model that is based on the model UAM version IV (Lurmann et al., 1997). Several modifications have been introduced in the UAM-AERO mesoscale model compared to the standard UAM-IV model, including new preprocessors for biogenic and natural emissions, new deposition routines and inorganic equilibrium chemistry module. In addition, 
gas-to-particle conversion routines are included for treating secondary formed inorganic and organic aerosols. The emission inventories are based on EMEP data (EMEP, 2003), whereas more detailed inputs for biogenic emission, resuspended dust, sodium and chlorine were calculated using newly developed methodologies combined with the UAMAERO model (Aleksandropoulou and Lazaridis, 2004). The model simulations were initiated $24 \mathrm{~h}$ before the beginning of each modeling period. This procedure was introduced to reduce the effect of not well defined initial conditions on the model results.

The UAM-AERO model allows the use of various alternative chemical mechanisms. The one employed for this case study is the Carbon Bond-IV (CB-IV), where species are lumped according to the type of their $\mathrm{C}-\mathrm{C}$ bonds. A large number of reactions, involving 47 species are taken into account. The CB-IV chemical scheme has a limitation of not considering the ambient temperature and the background aerosol concentration in the calculations of the secondary organic aerosols. This has also an effect on the production of secondary gaseous pollutants as the ozone (Griffin et al., 1999).

The meteorological inputs were obtained using the RAMS (version 4.29) prognostic meteorological model (Pielke et al., 1992). RAMS combines a non-hydrostatic cloud model (Tripoli and Cotton, 1982) and a hydrostatic mesoscale model (Mahrer and Pielke, 1977). It was developed for simulating atmospheric phenomena with resolutions ranging from tens of kilometres to a few metres. There is no lower limit to the domain size or to the grid cell size. A general description of the model and its capabilities is given in Pielke et al. (1992).

2.3 Application of the modeling system in the Eastern Mediterranean

The combined UAM-AERO and RAMS modelling framework has been applied to model the summer and winter campaigns of the EU project SUB-AERO held on the Finokalia station on Crete and aboard the research vessel "Aigeaion", which cruised across the Eastern Mediterranean area between the Greek mainland and Crete. Sampling took place during 4 weeks in July 2000 and at Finokalia for 1 week in January 2001.

The simulations were conducted for these two to investigate seasonal differences in the fate of the pollutants. Two sub-periods were examined for the summer period: 13-16 and 26-30 of July, the second one chosen to coincide with the marine part of the campaign.

The synoptic conditions over Central and Eastern Mediterranean in July 2000 were characterized by a high-pressure system over the Central and Eastern Mediterranean and north Africa. The passage of relatively shallow disturbances over south Europe towards the Balkans and the Black Sea strengthened the pressure gradient over NW Turkey and the
Dardanelles Gap. As a result, a westerly flow was evident on the 15th and 16th while on the following seven days the Etesians were established. During the summer period a characteristic flow pattern, the Etesians, appears over the Aegean Sea. This is a regional scale northerly flow with significant diurnal variation (Kallos et al., 1993). The Etesians are the result of the interaction of two major semi-stationary weather systems: the easterly extensions of the Azores anticyclone and the low pressure system over the Anatolian Plateau. This formation has as a result the development of a pressure gradient, which favors the transport of air masses from North to South. The Etesians are acting as a carrier for the transport of air pollutants from Eastern Europe towards the Eastern Mediterranean region.

Between 18-28 July 2000 the air flow over Finokalia was from the north and had earlier passed over the western coast of the Black Sea region and during the last three days of this period, where peak mass concentrations were observed, over the Aegean Sea. On the last two days, trajectories to Finokalia came from the southeast after having passed over north Africa and the Mediterranean Sea.

During the winter period the meteorological conditions were characterised by a low pressure system over the eastern part of the Mediterranean on 6 January 2001. There was a relatively strong northerly flow over the NE Mediterranean, which dissipated throughout the following 24-hours as the depression moved away towards the Middle East. To the west, a deep and extended Atlantic depression covered Central and Southern Europe. This system reached the Central Mediterranean on 8 January and then moved north-eastward through the Balkans towards the Black Sea region. From 8 to 9 January a southerly synoptic flow was established over the area of interest. As the depression moved away towards the Black Sea region, a high-pressure system progressively developed over the Central Mediterranean. On 10 January a relatively strong north-westerly synoptic flow was apparent over the Central and NE part of the Mediterranean. This flow dissipated throughout the following 24-h. On 11 to 12 January, the synoptic flow over the area under consideration was relatively weak. The wind field over the land was modified by the landscape. Over the Aegean maritime area a weak northerly current was established while over the Central Mediterranean and the Ionian Sea the synoptic flow was westerly. On 13 January a new depression from the west reached the Central Mediterranean while a strong anticyclonic circulation dominated over Central and Eastern Europe. These synoptic conditions favoured the development of a strong pressure gradient over the NE Mediterranean region. A strong southerly flow was evident over the Ionian Sea and the southern part of the Aegean while a strong easterly-northeasterly flow prevailed to the north.

The calculated spatial distribution of the concentration of ozone, nitrogen dioxide, sulphur dioxide, sodium, ammonium in the aerosol phase, carbon monoxide, resuspended dust and total $\mathrm{PM}_{10}$ are presented in Fig. 2 for 30 July 2000. 

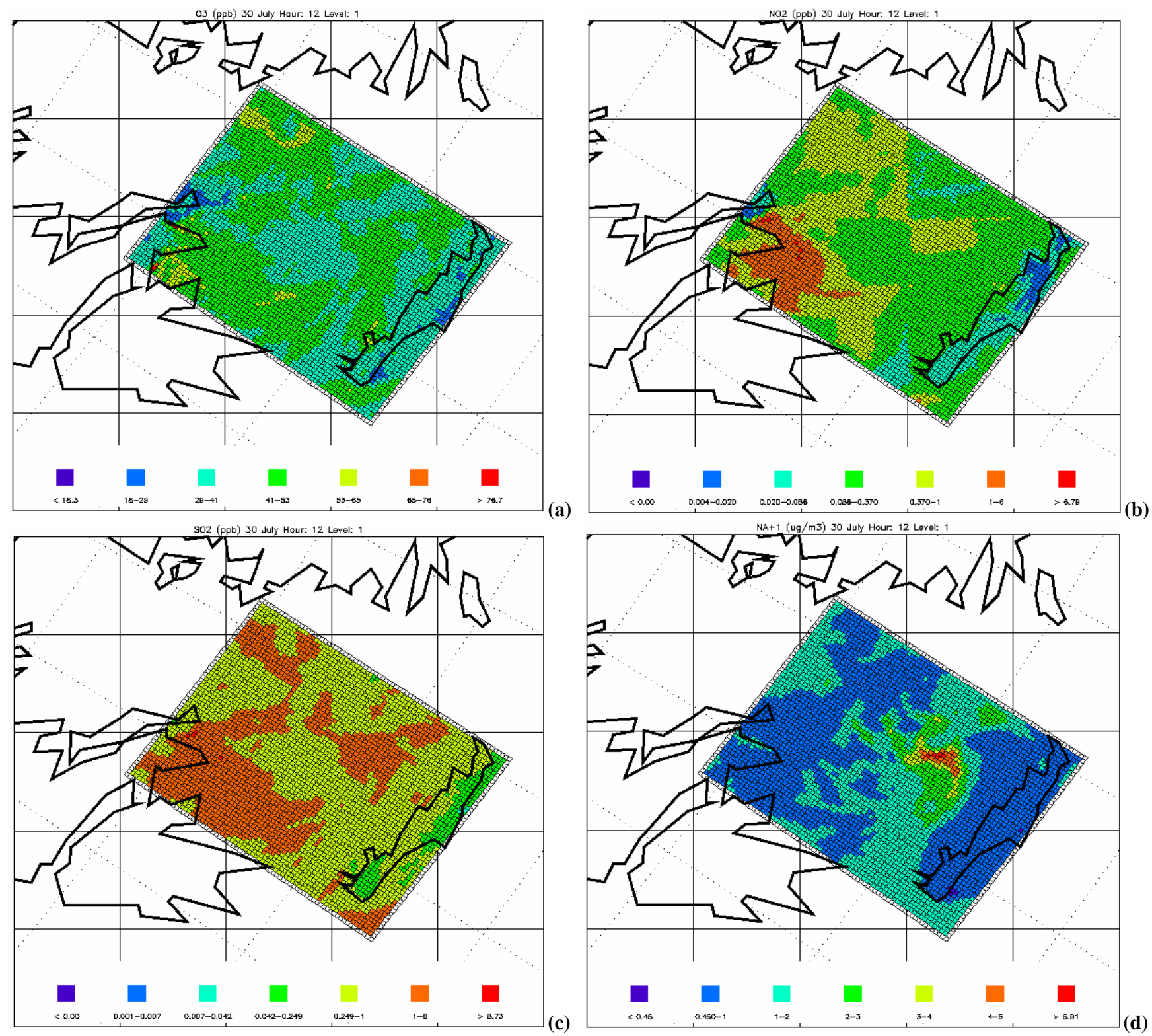

Fig. 2. Surface spatial distribution of (a) $\mathrm{O}_{3}$ (b) $\mathrm{NO}_{2}$ (c) $\mathrm{SO}_{2}$

(d) $\mathrm{Na}^{+}$(e) $\mathrm{NH}_{4}^{+}$(f) $\mathrm{CO}$, (g) resuspended dust and (h) $\mathrm{PM}_{10}$ at 30 July $12: 00 \mathrm{~h}$.

There are higher concentrations of particulate matter, carbon monoxide, nitrogen dioxide and ozone downwind of Athens and the transport of pollutants from outside the modelling domain is also important. The regional transport is related to the prevailing meteorological conditions. The predicted pattern of $\mathrm{O}_{3}$ shows a band of high concentrations extending from the Athens metropolitan area to the middle of the Aegean Sea and lower concentrations in a narrow area in the western part of the domain and above Crete.

The concentration of aerosol and gaseous pollutants in the area depends on the prevailing meteorological conditions, and it takes only a few hours for the boundary conditions to have a significant impact on the concentrations at the centre of the domain, as shown in Fig. 2 for $\mathrm{O}_{3}, \mathrm{NO}_{2}, \mathrm{SO}_{2}, \mathrm{PM}$ and $\mathrm{CO}$. Also natural emissions such as sea salt and resuspended dust are correlated with the meteorological fields in the modelling domain (Fig. 2d, g). The spatial distribution of $\mathrm{PM}_{10}$ reflects where sea salt is produced and agrees well with the primary PM emission patterns. The spatial pattern of sodium is high over the Aegean sea (average value of $3.5 \mu \mathrm{g} / \mathrm{m}^{3}$ onboard the research vessel "Aigeaion" between 26-29 July 2000 ) and lower onshore (average value of $1.5 \mu \mathrm{g} / \mathrm{m}^{3}$ during the summer measurement period), decreasing further with distance from the coastline. The spatial pattern agrees well with the primary PM emission patterns. 

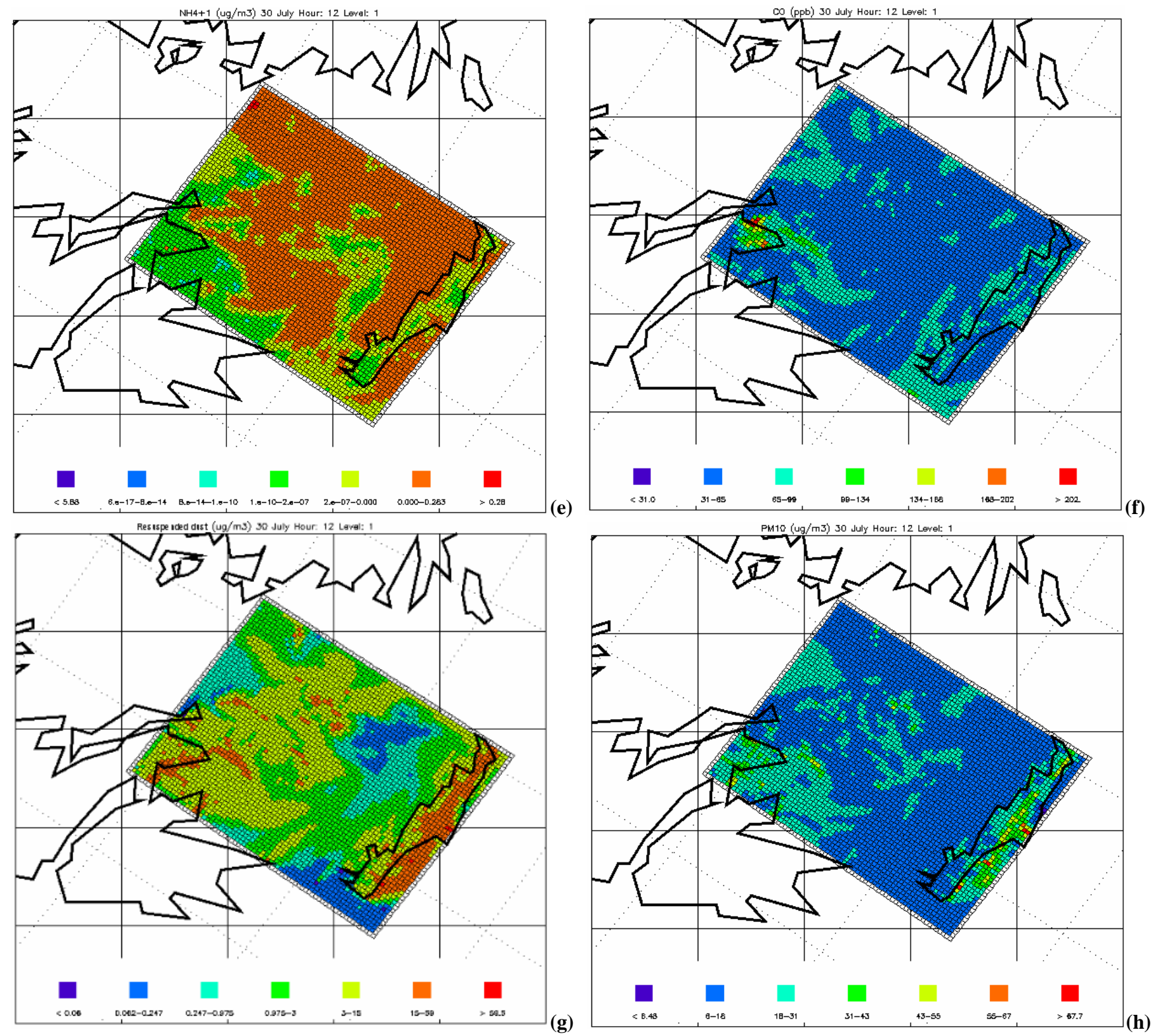

Fig. 2. Continued.

A diurnal variation of the $\mathrm{PM}_{10}$ concentration is shown in Fig. 3. Figure 3 depicts the dynamic change in the concentration of pollutants in the eastern Mediterranean due to meteorological changes and emissions from local areas. In the morning of 14 July (Fig. 3b) strong northwest winds bring in particulate matter from Athens to the southern part of the Aegean Sea at the same time as the sea salt emissions are considerable. The same meteorological conditions prevail until 10:00 h. At this time the wind changes to the northerly direction; Fig. 3b. From 17:00 h there is a decrease in the wind velocity with more stagnant meteorological conditions while at $21: 00 \mathrm{~h}$ the wind direction is from the west. It is evident that the meteorological conditions to a large extent are responsible for the dynamics of the pollutant concentrations in the area and the consequent human exposure. Elevated particulate matter concentrations are expected both when the air masses come from the west/north-west (western Europe and continental Greece) and from the south. The former would carry anthropogenic aerosols (with size distributions mainly in the fine sector), while the latter contributes to increases of coarse PM, transporting dust from North Africa and the Saharan Desert. The Black Sea region is expected to contribute to anthropogenic aerosols (combustion etc.) as well, while during easterlies contribution both to fine and coarse modes can be expected, depending on whether the airparcel crosses urban areas or deserts. 

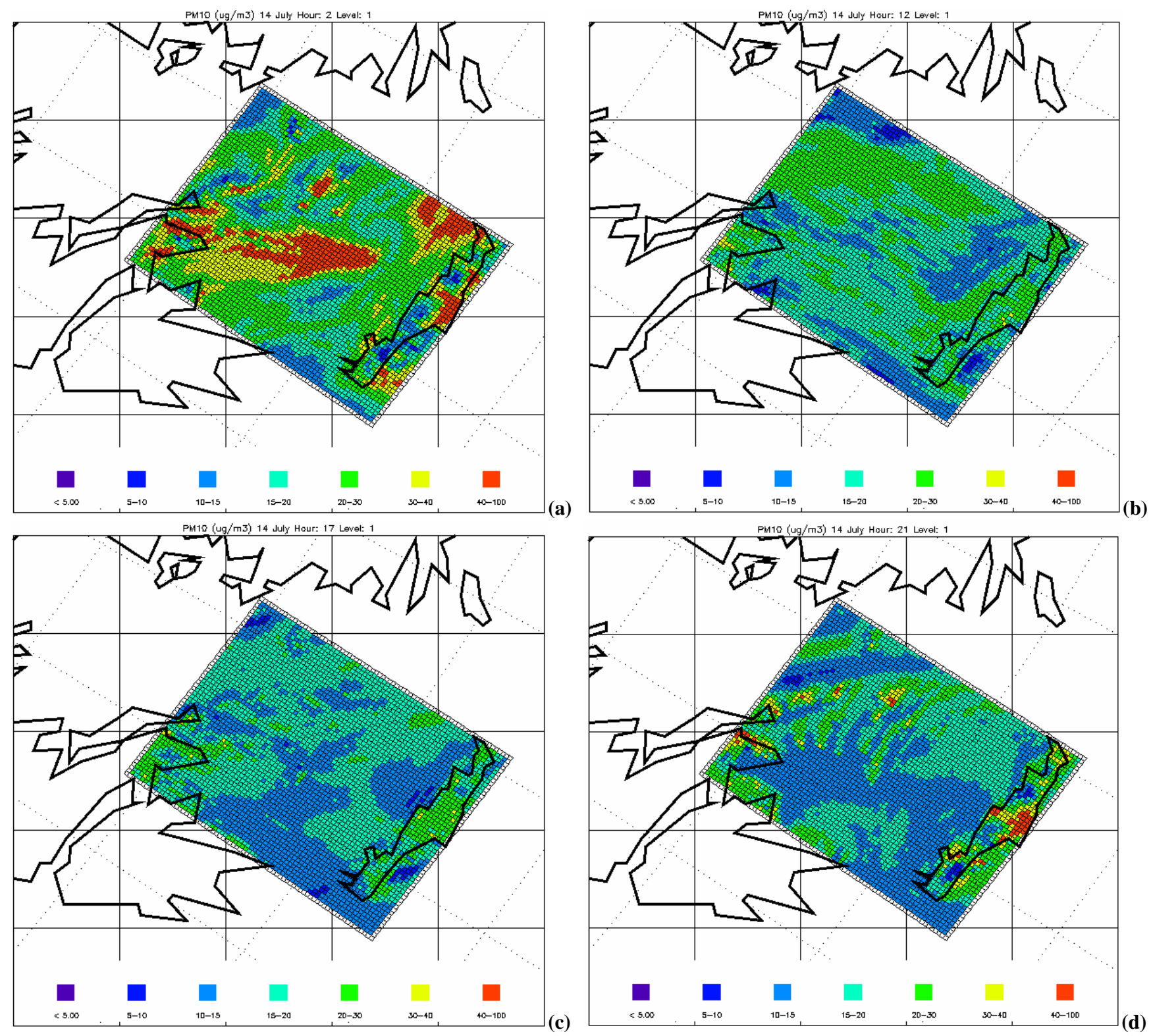

Fig. 3. Surface spatial distribution of $\mathrm{PM}_{10}$ at $14 \mathrm{July}$ at (a) $02: 00 \mathrm{~h}$ (b) $12: 00 \mathrm{~h} \mathrm{(c)} \mathrm{17:00} \mathrm{h}$ and (d) $21: 00 \mathrm{~h}$.

The regional transport for ozone and particulate matter can be also depicted in Fig. 4 where we present the surface concentration for the period 13-16 July 2000 at 12:00 h. A north westerly flow during this period is shown in Fig. 4 where elevated concentrations of ozone and particulate matter (e.g. Fig. $4 \mathrm{c}, \mathrm{d}$ ) infiltrating in the modelling domain. The same behaviour is also depicted for several chemical components such as carbon monoxide, nitrogen oxides, sulphur dioxide and volatile organic components.

Regional transport in the Mediterranean area of ozone and other pollutants is also occurring at higher altitudes and in the free troposphere as shown by others (Kouvarakis et al., 2000; Lelieveld et al., 2002). Here regional transport of ozone, particulate matter and other gaseous pollutants contributes to the pollutant levels in the area studied. An average calculated vertical profiles for ozone during January 2001 and July 2000 are shown in Fig. 5 for Finokalia, Herakleion and for an average profile over the sea. Ozone values range between 29 and 36 ppb for January 2001 whereas values between 34 and 38 have been calculated for July 2000. Surface ozone has a diurnal profile, determined by mixing height fluctuations. Downward flux of ozone from the free troposphere to the surface contributes to enhanced concentration levels. No observations of the vertical profiles of pollutants have been taken in the area and therefore the modelling results cannot be validated. 

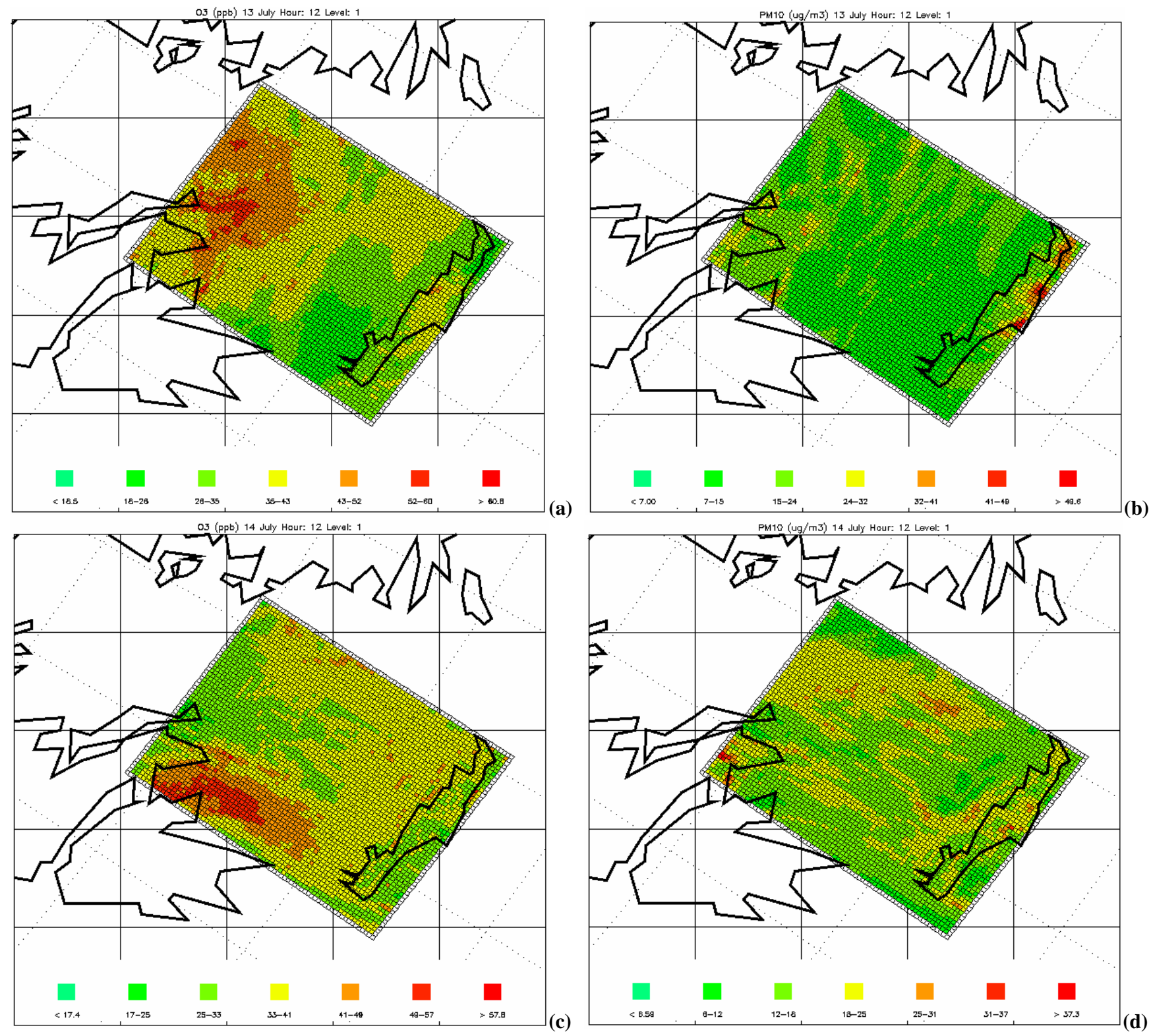

Fig. 4. Surface spatial distribution of $\mathrm{O}_{3}$ and $\mathrm{PM}_{10}$ for 13 July 2000 at 12:00 h (a-b), 14 July 2000 (c-d), 15 July 2000 (e-f) and 16 July 2000 (g-h).

The importance of regional transport of $\mathrm{PM}_{10}$ into the area of interest was further examined using the UAM-AERO model and setting the particulate emissions in the modelling domain to zero. The average reduction in the $\mathrm{PM}_{10}$ concentration inside the modelling domain ranged from $60 \%$ to $45 \%$ for the summer and winter modelling periods, respectively. The results here reflect the prevailing meteorological conditions during the modelling period. Forest fire emissions and Saharan dust input were not accounted for, and since the modelling period corresponds to only a few days no certain conclusions can be drawn for longer periods. However, the current results are supported by previous studies which showed the importance of the long range transport of pollutants in the Mediterranean area (Sciare et al., 2003; Zerefos et al., 2002).

Comparison with the experimental field data from the Finokalia station, Herakleion and onboard AIGEAION during the summer and winter periods is shown in Fig. 6 for $\mathrm{O}_{3}$. The variations of the modeled results both with the EMEP and the CTM-NILU models follow those of the measured data. Also, the diurnal variation of the predicted concentrations was in qualitative agreement with the measured data. Tables 3-5 show a quantitative comparison between modeled and measured gaseous species components for the measured periods. 

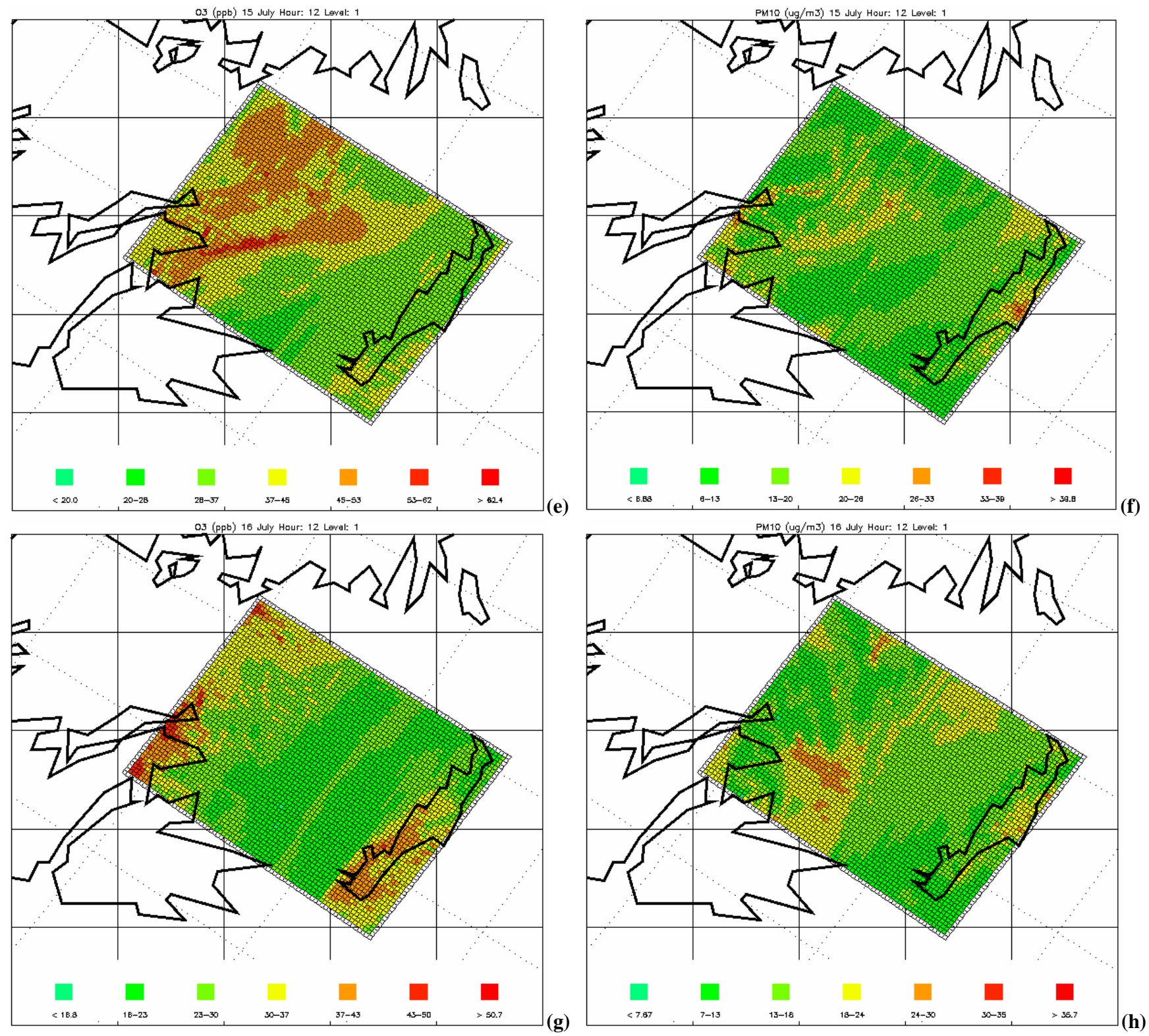

Fig. 4. Continued.

Average winter $\mathrm{O}_{3}$ vertical profiles at various environments

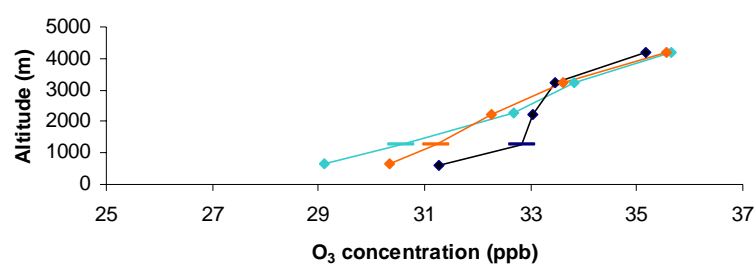

$\multimap$ Herakleion (NILU-CTM background) $\multimap$ Finokalia (NILU-CTM background) - Marine (NILU-CTM background)

Fig. 5. Average vertical profile of ozone during (a) January 2001 (b) July 2000 for three different environments using the UAM-AERO model. The CTM-NILU model was used for obtaining the initial and background ozone concentration.
Average summer $\mathrm{O}_{3}$ vertical profiles at various environments

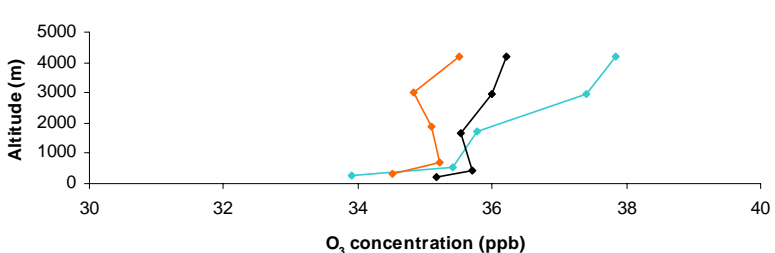

$\rightarrow-$ Herakleion (NILU-CTM background) $\rightarrow-$ Finokalia (NILU-CTM background)
$\rightarrow-$ Marine (NILU-CTM background)

(b) (a) 


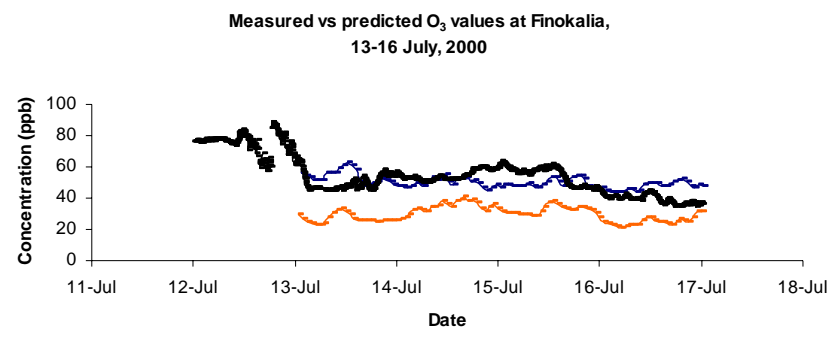

- modelled (NILU-CTM) —- modelled (EMEP) —-measured Measured versus predicted $\mathrm{O}_{3}$ values at Finokalia vs vessel, 26-30 July, 2000

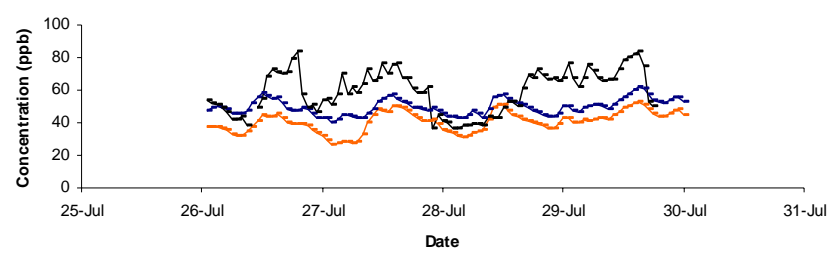

-modelled (NLU-CTM) — $\longrightarrow$ modelled (EMEP) — - measured

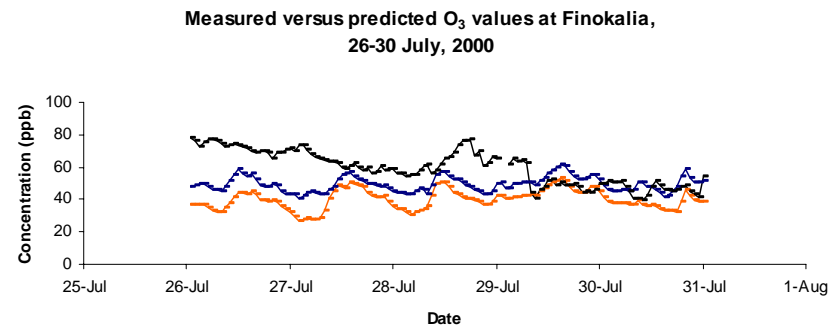

(a)

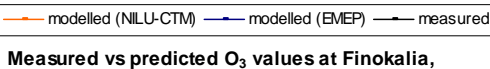
7-14 January, 2001

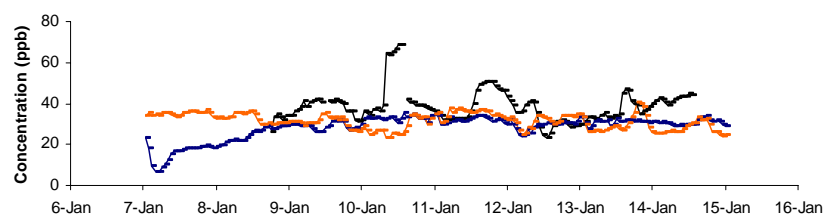

Date

(c) (b)

(d)

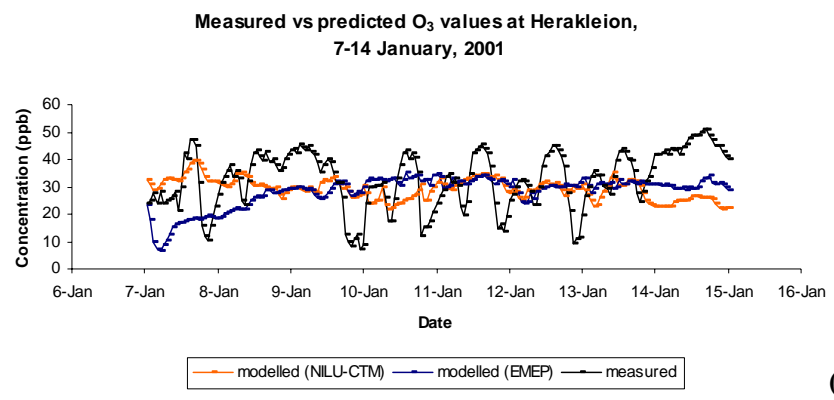

Fig. 6. Comparison between modeled (EMEP and NILU-CTM) and measured ozone mixing ratio for the period (a) $13-16$ July 2000 at Finokalia (b) 26-30 July 2000 at Finokalia (c) 26-30 July 2000 onboard the research vessel Aigeaion (d) 7-15 January 2001 at Finokalia (e) 7-15 January 2001 at Herakleion.

Chemically speciated PM

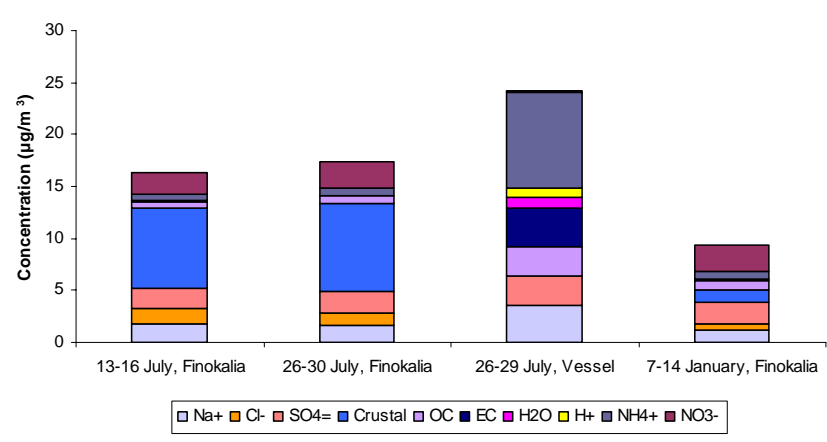

Fig. 7. Chemical averaged resolved $\mathrm{PM}_{10}$ mass between during the measurement periods (a) 13-16 July 2000 at Finokalia (b) 26-30 July 2000 at Finokalia (c) 26-29 July onboard the research vessel Agaion (d) 7-14 January 2001 at Finokalia.

Figure 7 shows the average modelled average daily profile of the chemical composition of $\mathrm{PM}_{10}$ for the period 13-
16, 26-30 July 2000 and 7-14 January 2001 at Finokalia and between 26-29 July onboard the research vessel Aigeon. Crustal material due to the resuspension from the soil surface dominates in the summer period. Elemental carbon is probably underestimated, since there were mainy fires in Greece during this period, and these were not accounted for in the model. Other important species are ammonium, sulphur, nitrates and sea-salt particles. From the $\mathrm{PM}_{10}$ composition data it is important to note the significant natural contribution (crustal oxides, sodium, chlorine) to the particulate matter mass during the summer period (close to 54\%); and close to $31 \%$ in winter. It must be noted that the model period is short and certain conclusions can not be drawn for longer periods. The average $\mathrm{PM}_{10}$ concentration during the research vessel campaign is also shown in Fig. 7. Elevated concentration has been calculated compared to the Finokalia station mainly due to elevated crustal materials. The meteorological conditions favour the regional transport during the period of the boat measurements. The average $\mathrm{PM}_{10}$ concentration during the winter campaign for Finokalia (January, 2001) shows that the 
Table 1. Comparison between experimental field data and modelling results (particulate matter chemical components) for the 1316 and 25-30 July 2000 periods at the Finokalia station.

\begin{tabular}{lll}
\hline$\mu \mathbf{g} / \mathbf{m}^{3}$ & Model Results & $\begin{array}{l}\text { Experimental } \\
\text { (Arith. Mean) }\end{array}$ \\
\hline & $\begin{array}{l}\text { July 2000 period } \\
\text { (Average) }\end{array}$ & $\begin{array}{l}\text { July 2000 period } \\
\text { (Average) }\end{array}$ \\
\hline Total PM10 & $20.8 \pm 3.77$ & $33.54 \pm 15.5$ \\
SO4= & $2.04 \pm 0.49$ & $6.88 \pm 0.96$ \\
NO3- & $2.23 \pm 0.85$ & $2.75 \pm 0.41$ \\
NH4+ & $1.58 \pm 0.10$ & $2.38 \pm 0.38$ \\
Na+ & $1.72 \pm 0.78$ & $1.92 \pm 0.28$ \\
Cl- & $1.28 \pm 1.11$ & $2.28 \pm 0.36$ \\
EC & $0.17 \pm 0.01$ & $0.44^{*} \pm 0.16$ \\
OC & $1.04 \pm 0.07$ & $1.32^{*} \pm 0.61$ \\
Crustal Oxides & $8.13 \pm 3.75$ & $7.58^{\#} \pm 3.50$ \\
\hline
\end{tabular}

Table 2. Comparison between experimental field data and modelling results particulate matter chemical components) for 7-14 January 2001 at the Finokalia station.

\begin{tabular}{lll}
\hline$\mu \mathbf{g} / \mathbf{m}^{3}$ & Model Results & $\begin{array}{l}\text { Experimental } \\
\text { (Arith. Mean) }\end{array}$ \\
\hline & $\begin{array}{l}\text { 7-14 January 2001 } \\
\text { (Average) }\end{array}$ & $\begin{array}{l}\text { 7-13 January 2001 } \\
\text { (Average) }\end{array}$ \\
\hline Total PM10 & $9.35 \pm 2.45$ & $14.55 \pm 6.5$ \\
SO4= & $2.18 \pm 0.64$ & $2.36 \pm 0.38$ \\
NO3- & $2.50 \pm 0.91$ & $1.53 \pm 0.23$ \\
NH4+ & $0.77 \pm 0.18$ & $0.77 \pm 0.086$ \\
Na+ & $1.11 \pm 0.46$ & $1.20 \pm 0.18$ \\
Cl- & $0.59 \pm 0.74$ & $2.06 \pm 0.30$ \\
EC & $0.20 \pm 0.05$ & $0.15^{*} \pm 0.04$ \\
OC & $0.83 \pm 0.2$ & $0.45^{*} \pm 0.19$ \\
Crustal Oxides & $1.14 \pm 0.87$ & $1.37^{\#} \pm 0.60$ \\
\hline
\end{tabular}

* TSP (Total Suspended Particles). The EC/OC measurements were performed for TSP ambient levels.

\# $1.16 *(1.90 * \mathrm{Al}+2.15 * \mathrm{Si}+1.41 * \mathrm{Ca}+1.67 * \mathrm{Ti}+2.09 * \mathrm{Fe})$

dominating species are sulphate, nitrate, and crustal material. Other important compounds are $\mathrm{Na}^{+}$and $\mathrm{Cl}^{-}$, typical for a coastal site.

In Tables 1-2 we present average predicted and observed chemical composition of particulate matter during the summer and winter simulation periods for 24-h averages. Modeled and observed $\mathrm{PM}_{10}$ agree better in the winter period than in the summer. Ammonium sulphate and crustal material dominate $\mathrm{PM}_{10}$ mass, whereas nitrate and sea salt also are important for the chemical mass closure. There is a discrepancy between the gravimetric measured $\mathrm{PM}_{10}$ concentra-
Table 3. Comparison between experimental field data and modelling results (gaseous species) for the 13-16 and 25-30 July 2000 periods at the Finokalia station.

\begin{tabular}{lll}
\hline Parameter & $\begin{array}{l}\text { Finokalia (Summer) } \\
\text { (ppbv) }\end{array}$ & $\begin{array}{l}\text { Model Results } \\
\text { (ppbv) }\end{array}$ \\
\hline $\mathrm{O}_{3}$ & $60 \pm 12.02$ & $50 \pm 4.25$ \\
$\mathrm{NO}_{2}$ & $2.25^{* * *}(10-20 / 7) \pm 0.85$ & $0.2 \pm 0.09$ \\
$\mathrm{NO}$ & $<0.05 \pm 0.08$ & $0.03 \pm 0.026$ \\
$\mathrm{SO}_{2}$ & $0.84^{*} \pm 0.72$ & $0.6 \pm 0.34$ \\
$\mathrm{HNO}_{3}$ & $0.45^{*}(20-30 / 7) \pm 0.41$ & $0.1 \pm 0.16$ \\
& $0.15^{* *}(10-20 / 7) \pm 0.17$ & \\
$\mathrm{HONO}$ & $0.13^{* *}(10-20 / 7) \pm 0.13$ & $0.05 \pm 0.001$ \\
\hline
\end{tabular}

*: from annular denuder measurements

*: prototype wet effluent diffusion denuder technique/chemiluniscent detection

**: prototype chemiluminescence ozone and nitrogen dioxide detectors

Table 4. Comparison between experimental field data and modelling results (gaseous species) for the period 26-29 July 2000 onboard the research vessel "Aigeaion".

\begin{tabular}{lll}
\hline Parameter & $\begin{array}{l}\text { Aegean sea (summer) } \\
\text { (ppbv) }\end{array}$ & $\begin{array}{l}\text { Model Results } \\
\text { (ppbv) }\end{array}$ \\
\hline $\mathrm{O}_{3}$ & $59.4 * * * \pm 13.25$ & $52.6 \pm 6.9$ \\
$\mathrm{NO}_{2}$ & $7.1 * * * \pm 7.59$ & $3.5 \pm 0.77$ \\
$\mathrm{SO}_{2}$ & $1.56^{*}$ & $2.1 \pm 1.08$ \\
$\mathrm{HNO}_{3}$ & $0.33^{*} \pm 0.76$ & $0.47 \pm 1.1$ \\
$\mathrm{HONO}$ & $0.12 * * \pm 0.36$ & $0.05 \pm 0.01$ \\
\hline
\end{tabular}

*: from annular denuder measurements

*: prototype wet effluent diffusion denuder technique/chemiluniscent detection

**: prototype chemiluminescence ozone and nitrogen dioxide detectors

Table 5. Comparison between experimental field data and modelling results (gaseous species) for 7-14 January 2001 at the Finokalia station.

\begin{tabular}{lll}
\hline Parameter & $\begin{array}{l}\text { Finokalia (Winter) } \\
\text { (ppbv) }\end{array}$ & $\begin{array}{l}\text { Model Results } \\
\text { (ppbv) }\end{array}$ \\
\hline $\mathrm{O}_{3}$ & $41.7 \pm 8.09$ & $31.3 \pm 3.8$ \\
$\mathrm{NO}_{2}$ & $0.52^{* * *} \pm 0.52$ & $0.7 \pm 0.11$ \\
$\mathrm{NO}$ & $<0.05$ & $0.02 \pm 0.04$ \\
$\mathrm{HNO}$ & $0.04^{* *} \pm 0.03$ & $0.02 \pm 0.18$ \\
$\mathrm{HONO}$ & $0.07^{* *} \pm 0.05$ & $0.03 \pm 0.004$ \\
\hline
\end{tabular}

*: from annular denuder measurements

*: prototype wet effluent diffusion denuder technique/chemiluniscent detection

**: prototype chemiluminescence ozone and nitrogen dioxide detectors 
Experimental vs. measured $\mathrm{SO}_{4}{ }^{\prime}$, at Finokalia, July 2000

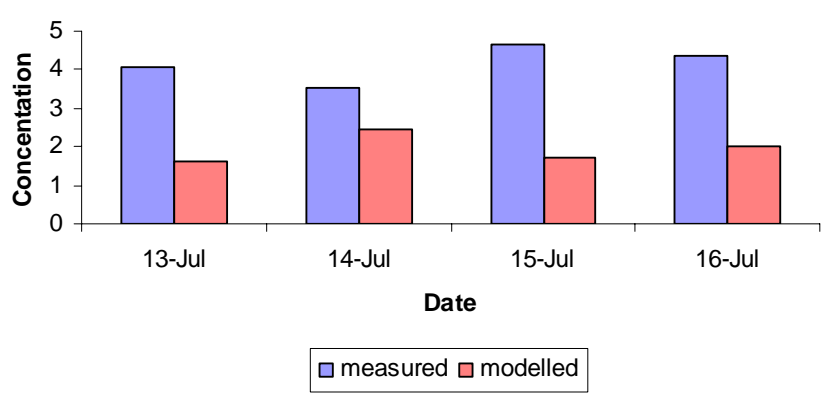

Fig. 8. Comparison between modelling and observed $\mathrm{SO}_{4}$ mass concentration between 13-16 July 2000 at the Finokalia station.

tions and the measured chemical resolved composition. This is due to organic mass, water and experimental errors. The concentration of particulate organic matter (POM) was determined by multiplying the OC concentration by 1.7 , which is the average ratio of the mass of carbon-containing species to carbon mass assumed to be distributed between the fine and coarse modes with a ratio of $7 / 3$ (Quinn et al., 2000). This may be an uncertainty factor in the calculation of the organic mass present in the $\mathrm{PM}_{10}$ concentration. For example Turpin et al. (2000) suggests a multiplication with 2.5 since the aerosol sampled was mainly of rural or background origin plus aged aerosol from distant anthropogenic sources, plus that elevated concentrations were observed due to forest fires (wood smoke). Furthermore, there is a discrepancy between modelled and measured particulate matter. Several factors such as forest fires and Saharan dust episodes which were observed during the summer period may be factors for this discrepancy (Smolík et al., 2003).

Tables 3-5 show the field concentration of trace gases, including those in equilibrium with aerosol species and their comparison with the modeling results for Finokalia during the summer period and on the research vessel "Aigeaion" and at Finokalia during the winter period. The modeling data follow the same general behaviour as the field observations.

The comparison between calculated and measured daily average $\mathrm{PM}_{10}$ levels for both the summer and winter periods show that there is a considerable underestimation of the $\mathrm{PM}_{10}$ mass during summer and better agreement in the winter. On 27 and 28 July Saharan dust episodes were identified to contribute significantly to the ambient $\mathrm{PM}_{10}$ concentration. This is a reason for the significant discrepancies between modeled and measured data. The Saharan dust episodes were identified based on satellite data, meteorological back trajectories and experimental field measurements which identified elevated concentrations of crustal materials. Average total $\mathrm{PM}_{10}$ from the modeling studies is $9.3 \mu \mathrm{g} / \mathrm{m}^{3}$ for the winter simulation and $20.8 \mu \mathrm{g} / \mathrm{m}^{3}$ for the summer period. The corresponding value for the measured data is $14.6 \mu \mathrm{g} / \mathrm{m}^{3}$ for the winter period and $33.5 \mu \mathrm{g} / \mathrm{m}^{3}$ for the
Experimental vs. measured $\mathrm{Na}^{+}$mass $\left(\mathrm{PM}_{10}\right)$, at Finokalia, January 2001

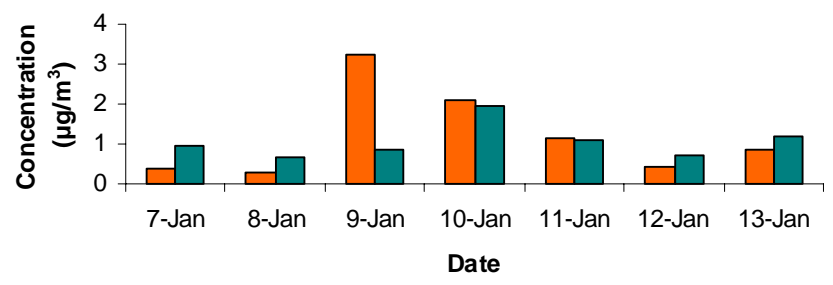

$\square$ measured $\square$ modelled

Fig. 9. Comparison between modelling and observed $\mathrm{Na}^{+}$mass concentration between 7-13 January 2001 at the Finokalia station.

summer period. The difference in the concentration levels may also be attributed to an underestimation of several chemical fractions of the PM mass. There is an underestimation of chlorine and sodium (sea salt) particulate matter emissions, and an underestimation of the sulphate mass and crustal materials from Saharan dust episodes. In addition, forest fires in July 2000 contributed to PM mass but were not included in the modelling study. Furthermore, an important fraction of the measured particulate matter has not been chemically characterized, so that the comparison between model results and measured data is uncertain. The $\mathrm{NO}_{3}^{-}, \mathrm{NH}_{4}^{+}, \mathrm{OC}$ and $\mathrm{EC}$ concentrations are in good agreement with the measured data as shown in Tables 1-2. It has to be stressed that the meteorological conditions influence considerably the ambient particulate matter concentration and chemical composition since for example NW winds at the Finokalia station lead to enhanced sea salt concentrations. Furthermore, it has to be stressed that the modelled results are based on average values on a $5 \times 5 \mathrm{~km}^{2}$ grid whereas the measured data at the research station of Finokalia or the onboard the research vessel Aigeaion and this may introduce a source of error in performing the comparison between modelled and measured data.

Figure 8 presents a comparison between measured and predicted $\mathrm{SO}_{4}^{=}$levels, for Finokalia in July 2000. There is poor agreement between modelled and measured data (modeled data: $2.04 \pm 0.49 \mu \mathrm{g} / \mathrm{m}^{3} ; 6.88 \pm 0.96 \mu \mathrm{g} / \mathrm{m}^{3}$ ). The sources for $\mathrm{SO}_{4}^{=}$are mainly anthropogenic from the Greek mainland and from long range transport. The $\mathrm{SO}_{4}^{=}$particles are mainly emitted from industrial sources. The existence of the State Electricity Organization power plant at Herakleion, as well as air-masses that originate from Athens can strongly influence the levels observed on Crete.

Figure 9 shows the comparison between modeled and measured concentrations for $\mathrm{Na}^{+}$. Sea salt particles are strongly affected by the wind and make an important contribution at Finokalia. The modeling data are in general in good agreement with the measured data (modeled data: 
$1.11 \pm 0.46 \mu \mathrm{g} / \mathrm{m}^{3}$; measured data: $1.20 \pm 0.18 \mu \mathrm{g} / \mathrm{m}^{3}$ ) except on 9 January where the average measured $\mathrm{Na}^{+}$concentration is around $3.1 \mu \mathrm{g} / \mathrm{m}^{3}$ whereas the modeled value is $1.0 \mu \mathrm{g} / \mathrm{m}^{3}$.

Although the simulation periods are too short to allow seasonal variability of the pollutants to be established, differences between the summer and winter periods are clear both in terms of quantities and diurnal variation patterns. Pollutants determined largely by the solar radiation level are more stable during daytime. At the same time the values measured in winter are a lot lower than in summer for ozone, isoprene, PAN, $\mathrm{OH}$ and other photooxidants, while the precursors levels are elevated ( $\mathrm{NO}, \mathrm{NO}_{2}$, etc.). Especially, particulate matter concentrations are lower during the winter mainly due to reduced dust resuspension from the soil and low photochemical activity.

\section{Conclusions}

The combined UAM-AERO/RAMS modeling system is an efficient platform for the simulation of the transport/dynamics of particulate matter and photo-oxidant precursors and fits the purpose to use it for simulating the performed field campaigns.

The UAM-AERO model was applied to simulate PM and photo-oxidants in the eastern Mediterranean area.

Using the combined UAM-AERO and CTM-NILU it is seen how important photo-oxidant and fine aerosols dynamics is in the Mediterranean area, and how regional transport contribute significantly to the observed pollution levels. When comparing with measurements, the modelling results underestimate the $\mathrm{PM}_{10}$ measured concentrations during summer. For the winter experimental campaign the comparison between the model results and the experimental data is slightly better but under-prediction for the total $\mathrm{PM}_{10}$ levels is also observed.

Discrepancies between modelled and measured data for the particulate matter are probably mainly due to unresolved particulate matter emissions such as Saharan dust and forest fire emissions during the summer period. The measured values show that resuspension from soil is an important factor in determining the aerosol size distribution during the summer period. A need for chemical quantification of particulate matter emission inventories in Europe is demonstrated, together with a need for determination of the effect of Saharan dust, wild forest fires, and resuspended dust emissions in Southern Europe.

From the modelling results and the comparison with the measured data it can be concluded that the Eastern Mediterranean is characterized by a heavy aerosol load during summer composed of anthropogenic $\left(\mathrm{SO}_{4}^{=}, \mathrm{NO}_{3}^{-}\right)$and biogenic $\left(\mathrm{NH}_{4}^{+}\right)$material, Saharan dust and sea-emitted/natural $\left(\mathrm{Na}^{+}\right.$, $\mathrm{Cl}^{-}$) aerosols. Transport contributes significantly to the high levels observed at remote sites. The most common species are related to the existence of sulfate, nitrate, am- monium ions, sea salt and Saharan dust, with the formation of $\left(\mathrm{NH}_{4}\right)_{2} \mathrm{SO}_{4}$ among the most important secondary aerosol, as also observed from measurements and supported by the modelling results (Kouvarakis et al., 2002).

Acknowledgements. This work was supported by the European Commission under grant ENVK2-1999-00052. We would like to thank Z. Večeřa and P. Mikuška (Czech Academy of Science, Czech Republic) and also N. Mihalopoulos (University of Crete, Greece) for providing the ozone data. We would like also to thank S. Pandis (Carnegie Mellon University) for his helpful comments and suggestions.

Edited by: R. A. MacKenzie

\section{References}

Ackermann, I. J., Hass, H., Memmesheimer, M., Ebel, A., Binkowski, F. S., and Shankar, U.: Modal aerosol dynamics model for Europe: Development and first applications, Atmos. Environ., 32, 2981-2999, 1998.

Aleksandropoulou, V. and Lazaridis, M.: Study of gaseous and particulate matter emissions in Greece, Water, Air, Soil Pollut., 153, 15-34, 2004.

Andreae, M. O.: In Future Climates of the World: A Modelling perspective (Climatic effects of changing atmospheric aerosol levels), A. Henderson-Sellers, Macquarie University, Climatic Impacts Centre, Australia, 1995.

ApSimon, H. M., Gonzalez del Campo, M. T., and Adams, H. S.: Modelling long-range transport of primary particulate material over Europe, Atmos. Environ., 35, 343-352, 2001.

Bardouki, H., Liakakou, H., Economou, C., Sciare, J., Smolík, J., Ždímal, V., Eleftheriadis, K., Lazaridis, M., and Mihalopoulos, N.: Chemical composition of size resolved atmospheric aerosols in the eastern Mediterranean during summer and winter, Atmos. Environ., 37, 195-208, 2003.

Benkovitz, C. M., Scholtz, M. T., Pacyna, J., Tarrason, L., Dignon, J., Voldner, E. C., Spiro, P. A., Logan, J. A., and Graedel, T. E.: Global gridded inventories of anthropogenic emissions of sulfur and nitrogen, J. Geophys. Res.-A, 101(D22), 29 239-29253, 1996.

Berdowski, J. J. M., Mulder, W., Veldt, C., Vesschedijk, A. J. H., and Zandved, P. Y. J.: Particulate matter emissions ( $\mathrm{PM}_{10^{-}}$ $\mathrm{PM}_{2.5}-\mathrm{PM}_{0.1}$ ) in Europe in 1990 and 1993, Technical Report, Netherlands organization fro Applied Scientific Research, TNOMEP-R 96/472, Apeldoorn, the Netherland, 1997.

Binkowski, F. S. and Shankar, U.: The regional particulate model 1. Model description and preliminary results, J. Geophys. Res., 100, 26 191-26 209, 1995.

EMEP/CORINAIR: Atmospheric Emission Inventory Guidebook, 3rd Edition, Prepared by the EMEP Task force on Emission Inventories, EEA Technical Report No. 30, 2002.

EMEP-WMO: Workshop on Strategies for Monitoring of Regional Air Pollution in relation to the need within EMEP, GAW and other international bodies, EMEP/CCC-Report 10/97, 1997.

Flatøy, F., Hov, Ø., and Schlager, H.: Chemical forecasts used for measurement flight planning during the POLINAT 2., Geophys. Res. Lett., 27, 951-954, 2000. 
Griffin, R. J., Cocker III, D. R., Flagan, R. C., and Seinfeld, J. H.: Organic Aerosol formation from oxidation of biogenic hydrocarbons, J. Geophys. Res., 104, 3555-3567, 1999.

Guenther, B., Zimmerman, P. R., Harley, P. C., Monson, R. K., and Fall, R.: Isoprene and monoterpene rate variability: Model evaluations and sensitivity analysis, J. Geophys. Res., 98(10), 12609 12 617, 1993.

Jacobson, M. Z.: Development and application of a new air pollution modeling system - II: Aerosol module structure and design, Atmos. Environ., 31A, 131-144, 1997.

Kallos, G., Kotroni, V., Lagouvardos, K., and Papadopoulos, A.: On the transport of air pollutants from Europe to North Africa, Geophys. Res. Lett., 25(5), 619-622, 1999.

Kallos, G., Kassomenos, P., and Pielke, R. A.: Synoptic and mesoscale weather conditions during air pollution episodes in Athens, Greece, Boundary-Layer Meteorol., 62, 163-184, 1993.

Kouvarakis, G., Tsigaridis, K., Kanakidou, M., and Mihalopoulos, N.: Temporal variations of surface regional background ozone over Crete Island in the southeast Mediterranean, J. Geophys. Res., 105, 4399-4407, 2000.

Lazaridis, M., Spyridaki, A., Solberg, S., Kallos, P. G., Svendby, T., Flatoy, F., Drossinos, I., Housiadas, C., Smolík, J., Colbeck, I., Varinou, M., Gofa, F., Eleftheriadis, K., Zdimal, V., and Georgopoulos, P. G.: Modeling of combined aerosol and photooxidant processes in the Mediterranean area, Water, Air, Soil Pollut. - Focus, 4, 4-5, 3-21, 2004.

Lelieveld, J., Berresheim, H., Borrmann, S., Crutzen, P. J., Dentener, F. J., Fischer, H., Feichter, J., Flatau, P. J., Heland, J., Holzinger, R., Korrmann, R., Lawrence, M. G., Levin, Z., Markowicz, K. M., Mihalopoulos, N., Minikin, A., Ramanathan, V., de Reus, M., Roelofs, G. J., Scheeren, H. A., Sciare, J., Schlager, H., Schultz, M., Siegmund, P., Steil, B., Stephanou, E. G., Stier, P., Traub, M., Warneke, C., Williams, J., and Ziereis, H.: Global air pollution crossroads over the Mediterranean, Science, 298, 794-799, 2002.

Lurmann, F. W., Wexler, A. S., Pandis, S. N., Mussara, S., Kumar, N., and Seinfeld, J. H.: Modelling Urban and Regional Aerosols - II, Application to California's South Coast Air Basin, Atmos. Environ., 31, 2695-2715, 1997.

Mihalopoulos, N., Stephanou, E., Kanakidou, M., Pilitsidis, S., and Bousquet, P.: Tropospheric aerosol ionic composition in the Eastern Mediterranean region, Tellus Ser. B-Chem. Phys. Meteorol., 49, 314-326, 1997.

Monahan, E. C., Spiel, D. E., and Davidson, K. L.: A model of marine aerosol generation via whitecaps and wave disruption, in Oceanic whitecaps, edited by: Monahan, E. C. and Mac Niocail, G., 167-174, D. Reidel, Norwell, MA, 1986.

Pai, P., Vijayaraghavan, K., and Seigneur, C.: Particulate matter modeling in the Los Angeles basin using the SAQM-AERO, J. Air \& Waste Management Association, 50, 32-42, 2000.

Pandis, S. N., Harley, R. A., Cass, G. R., and Seinfeld, J. H.: Secondary organic aerosol formation and transport, Atmos. Environ., 26A, 2269-2282, 1992.

Peters, L. K., Berkowitz, C. M., Carmichael, G. R., Easter, R. L., Fairweather, G., Ghan, S. J., Hales, J. M., Leung, L. R., Pennell, W. R., Potra, F. A., Saylor, R. D., and Tsang, T. T.: The current state and future direction of eulerian models in simulating tropospheric chemistry and transport of trace species: a review, Atmos. Environ., 29, 189-222, 1995.
Pielke, R. A., Cotton, W. R., Walko, R. L., Tremback, C. J., Lyons, W. A., Grasso, L. D., Nicholls, M. E., Moran, M. D., Wesley, D. A., Lee, T. J., and Copeland, J. H.: A comprehensive Meteorological Modeling System - RAMS. Meteorol. Atmos. Phys., 49, 69-91, 1992.

Pilinis, C. and Seinfeld, J. H.: Continued development of a general equilibrium model for inorganic multicomponent atmospheric aerosols, Atmos. Environ., 21, 2453-2466, 1987.

Quinn, P. K., Bates, T. S., Coffman, D. J., Miller, T. L., Johnson, J. E., Covert, D. S., Putaud, J. P., Neususs, C., and Novakov, T. Comparison of aerosol chemical and optical properties from the 1st and 2nd Aerosol Characterization Experiments, Tellus, 52B, 239-257, 2000.

Russell, A. and Dennis, R.: NARSTO critical review of photochemical models and modeling, Atmos. Environ., 34, 2283-2324, 2000.

Sciare, J., Bardouki, H., Moulin, C., and Mihalopoulos, N.: Aerosol sources and their contribution to the chemical composition of aerosols in the Esatern Mediterranean Sea during summertime, Atmos. Chem. Phys., 3, 291-302, 2003,

SRef-ID: 1680-7324/acp/2003-3-291.

Seigneur, C.: Current status of air quality models for particulate matter, J. Air \& Waste Management Association, 51, 1508-1521, 2001.

Seinfeld, J. H. and Pandis, S. N.: Atmospheric chemistry and physics - From air pollution to Climate change, John Wiley and Sons Inc, New York, 1998.

Simpson, D., Guenther, A., Hewitt, C. N., and Steinbrecher, R.: Biogenic emissions in Europe, J. Geophys. Res., 100(D11), 22 875-22 890, 1995.

Simpson, D., Winiwarter, W., Borjesson, G., et al.: Inventorying emissions from nature in Europe, J. Geophys. Res.-A. 104(D7), 8113-8152, 1999.

Smith, M. H., Park, P. M., and Consterdine, I. E.: Marine aerosol concentration and estimated fluxes over seas, Q. J. R. Meteorol Soc., 119 (512), 809-824, Part A, 1993.

Smolík, J., Ždímal, V., Schwartz, J., Lazaridis, M., Havranek, V., Eleftheriadis, K., Mihalopoulos, N., Bryant, C., and Colbeck, I.: Size resolved mass concentration and elemental composition of atmospheric aerosols over the Eastern Mediterranean area, Atmos. Chem. Phys., 3, 2207-2216, 2003,

SRef-ID: 1680-7324/acp/2003-3-2207.

Sotiropoulou, R. E. P., Tagaris, E., Pilinis, C., Andronopoulos, S., Sfetsos, A., and Bartzis, J. G.: The BOND project: Biogenic aerosols and air quality in Athens and Marseille greater areas, J. Geophys. Res., 109, D05205, 2004.

Thomas, G. E. and Stamnes, K.: Radiative Transfer in the Atmosphere and Ocean, Cambridge University Press, New York, 1999.

Turpin, J. B., Saxena, P., and Andrews, E.: Measuring and simulating particulate organics in the atmosphere: problems and prospects, Atmos. Environ., 34, 2983-3013, 2000.

Zerefos, C. S., Kourtidis, K., Melas, D., Balis, D., Zanis, P., Katsaros, L., Mantis, H. T., Repapis, C., Isaksen, I., Sundet, J., Herman, J., Bhartia, P. K., and Calpini, B.: Photochemical Activity and Solar Ultraviolet Radiation (PAUR) Modulation Factors: An overview of the project, J. Geophys. Res.-A, 107(D18), 81348148, 2002. 